\title{
Insulin Regulation of Rat Growth Hormone Gene Transcription
}

\author{
Shunichi Yamashita and Shlomo Melmed \\ Department of Medicine, Cedars-Sinai Medical Center, University of California \\ at Los Angeles School of Medicine, Los Angeles, California 90048
}

\begin{abstract}
We have previously shown that insulin suppresses growth hormone (GH) messenger (m) RNA levels in rat pituitary cells. To further delineate the molecular mechanism of insulin action, the effect of insulin treatment on GH gene transcription rates was examined in $\mathbf{G H}_{3}$ pituitary cells grown in serum-free defined medium. A transcriptional run-off assay was performed when intact isolated nuclei were allowed to continue RNA synthesis in an in vitro reaction. Specific incorporation of $\left.\right|^{32} \mathbf{P} \mid G T P$ into RNA was quantified by hybridization to rat GH complementary (c) DNA. Hybridization efficiency was measured with an internal [ $\left.{ }^{3} \mathrm{H}\right] \mathrm{CRNA}$ standard and ranged from 30 to $48 \%$. Alpha-amanitin $(1 \mu \mathrm{g} / \mathrm{ml})$ inhibited total transcription, and excess unlabeled rat pituitary mRNA (250 ng) competitively inhibited GH mRNA hybridization by $>\mathbf{8 0} \%$. Insulin (0.7 $\mathrm{nM})$ inhibited new GH mRNA synthesis, and maximal inhibition (30\% of control) was observed with $7 \mathrm{nM}$ insulin after $4 \mathrm{~h}$ treatment. The inhibitory effects of insulin on new GH mRNA synthesis were abolished by both insulin-receptor-antiserum and by guinea-pig anti-insulin serum. The results show that insulin exerts a rapid suppression of new GH mRNA synthesis. These data provide evidence for the direct transcriptional regulation of the $\mathbf{G H}$ gene by insulin.
\end{abstract}

\section{Introduction}

Insulin action at the cellular level includes rapid metabolic effects and relatively slower effects on gene expression and protein synthesis $(1,2)$. Insulin directly inhibits the transcription of the phosphoenolpyruvate carboxykinase (PEPCK) gene (3), and stimulates albumin gene transcription (4). Furthermore, insulin has been shown to regulate the level of several specific messenger RNAs including those for amylase (5), tyrosine aminotransferase (6), fatty acid synthetase (7), pyruvate kinase (8), alpha $2 \mu$ globulin (9), growth hormone $(\mathrm{GH})^{1}(10,11)$, and glyceraldehyde3-phosphate dehydrogenase (12).

The hypothalamic regulation of pituitary $\mathrm{GH}$ secretion is mediated by growth hormone releasing hormone (GHRH) and somatostatin (13). GHRH stimulates GH secretion, and somatostatin inhibits GH secretion. Peripheral hormones, includ-

\section{Address correspondence to Dr. Melmed. \\ Received for publication 25 February 1986 and in revised form 3 June 1986.}

1. Abbreviations used in this paper: DTT, dithiothreitol; GH, growth hormone; GHRH, growth hormone releasing hormone; IGF, insulinlike growth factor; mRNA, messenger RNA; NC, nitrocellulose paper; ppm, parts per million; PEPCK, phosphoenolpyruvate carboxykinase.

J. Clin. Invest.

(C) The American Society for Clinical Investigation, Inc.

0021-9738/86/10/1008/07 \$1.00

Volume 78, October 1986, 1008-1014 ing $T_{3}(14)$, hydrocortisone $(15,16)$, and insulin-like growth factor-I (17) have also been shown to modulate $\mathrm{GH}$ messenger (m) RNA levels. Both $\mathrm{T}_{3}$ and hydrocortisone exert a direct transcriptional effect on GH gene expression (18-21). Although insulin has been shown to inhibit GH secretion and GH mRNA levels in $\mathrm{GH}_{3}$ rat pituitary tumor cells $(10,22)$, and in normal rat pituitary cells (11), it is unclear whether the inhibitory effects of insulin occur at the level of GH gene transcription or whether they are in fact posttranscriptional. The suppression of $\mathbf{G H}$ mRNA levels by insulin may be due to a direct inhibition of GH gene transcription, as has been demonstrated for the PEPCK gene (4). Alternatively, a more distal effect of insulin on GH gene expression appears possible because insulin has been shown to inhibit induction of GH mRNA levels by $\mathrm{T}_{3}$ and hydrocortisone in $\mathrm{GH}_{3}(10)$ and by GHRH in normal pituitary cells (11). The net decrease of GH mRNA by insulin may reflect a decrease in GH gene transcription rates, or changes in GH mRNA processing, transport, or degradation (23).

Therefore, to clarify the inhibitory mechanism of insulin on GH gene expression, we examined the effects of insulin on new $\mathrm{GH}$ mRNA synthesis in $\mathrm{GH}_{3}$ rat pituitary cells in a nuclear runoff transcription assay. These cells were chosen because they have been extensively studied as models for $\mathrm{GH}$ gene regulation by other hormones (18-21). They have also been found to be responsive to physiological levels of insulin in inhibiting $\mathbf{G H}$ secretion and mRNA levels $(10,22)$, and have recently been shown to contain relatively high levels of insulin receptors (2426). The results shown here indicate that insulin directly regulates the transcriptional activity of the GH gene in these cells.

\section{Methods}

Cells. $\mathrm{GH}_{3}$ rat pituitary cells, secreting $\mathrm{GH}$ and prolactin (PRL) (27) were obtained from the American Type Culture Collection, Rockville, MD. $\sim 10^{6}$ cells were plated in $175-\mathrm{cm}^{2}$ flasks. Cells were grown at $37^{\circ} \mathrm{C}$ in a humidified atmosphere of $95 \%$ air-5\% $\mathrm{CO}_{2}$. After 7-10 d of monolayer culture in Ham's F-10 medium containing horse serum (15\%) and fetal calf serum (2.5\%), cells were 70-80\% confluent. Medium was then aspirated and replaced with serum-free medium $\left(0.5 \mathrm{nM} \mathrm{T}_{3}, 1 \mathrm{nM}\right.$ hydrocortisone, $0.02 \mathrm{nM}$ parathyroid hormone, transferrin $10 \mu \mathrm{g} / \mathrm{ml}$, and $0.3 \%$ bovine serum albumin in Dulbecco's modified Eagle's medium) with or without added semisynthetic purified insulin (E. R. Squibb \& Sons, Princeton, NJ). The durations of these test incubations were from 1 to $72 \mathrm{~h}$. At the end of the test incubations nuclei were isolated from the cells and transcriptional run-off assays were performed (28).

Preparation of nuclei from cells. Medium was sterilely removed and $20 \mathrm{ml}$ of sterile ice-cold $0.01 \mathrm{M}$ phosphate-buffered saline (PBS), $\mathrm{pH} 7.4$, was added to flasks which were kept cold. Cells were scraped from flasks using disposable cell scrapers (Corning Glass Works, Corning, NY) and the cell suspension was transferred to a sterile 50-ml test tube kept on ice. Cell number in a 50- $\mu$ l aliquot was counted using an automatic cell counter. The cells were centrifuged $\left(500 \mathrm{~g}, 10 \mathrm{~min}\right.$ at $\left.4^{\circ} \mathrm{C}\right)$ and resuspended in $0.32 \mathrm{M}$ sucrose, $3 \mathrm{mM} \mathrm{CaCl} 2,2 \mathrm{mM}$ magnesium acetate, 0.1 mM EDTA, $10 \mathrm{mM}$ Tris $\mathrm{HCl}, \mathrm{pH} \mathrm{8.0,}$, at a density of $5 \times 10^{6}-2 \times 10^{7}$ cells $/ \mathrm{ml}$. To disrupt the cell membrane, $0.1 \%$ Triton-X and $1 \mathrm{mM}$ dithiothreitol (DTT) were then added. The cells were homogenized (10- 
15 strokes) in a glass homogenizer (Dounce, Millville, NJ) fitted with a tight pestle. The homogenate was diluted with $2 \mathrm{vol}$ of $2 \mathrm{M}$ sucrose, 5 $\mathrm{mM}$ magnesium acetate, $0.1 \mathrm{mM}$ EDTA, $10 \mathrm{mM}$ Tris $\mathrm{HCl}$, $\mathrm{pH} 8.0$, and $1 \mathrm{mM}$ DTT, and then layered over a $10-\mathrm{ml}$ cushion of the $2 \mathrm{M}$ sucrose buffer, and centrifuged at $30,000 \mathrm{~g}$ for $45 \mathrm{~min}$, at $4^{\circ} \mathrm{C}$. After decanting, the nuclei were resuspended in $100-200 \mu \mathrm{l}$ of $25 \%$ glycerol, $5 \mathrm{mM} \mathrm{Mg}$ acetate, $5 \mathrm{mM}$ DTT in $0.1 \mathrm{mM}$ EDTA, $50 \mathrm{mM}$ Tris $\mathrm{HCl}, \mathrm{pH} 8.0$. All buffers contained inhibitors of endogenous nucleases and proteases $(0.1$ mM phenylmethylsulfonyl fluoride, $1 \mathrm{mM}$ EGTA, and $1 \mathrm{mM}$ spermidine).

Synthesis of radiolabeled RNA in isolated nuclei. Nuclei were incubated with ATP, CTP, and UTP ( $2 \mathrm{mM}$ each), $0.2 \mathrm{mM} \mathrm{GTP}, 0.1 \mathrm{mM}$ S-adenosylmethionine, and $\left.{ }^{32} \mathrm{P}\right]$ guanosine 5 -triphosphate $(800 \mathrm{Ci} / \mathrm{mmol}$, $20 \mu \mathrm{l})$ in $0.15 \mathrm{M} \mathrm{KCl}$ and $3 \mathrm{mM} \mathrm{Mg}$ acetate (28). The transcription reaction, in a total volume of $200 \mu \mathrm{l}$, was continued for $45 \mathrm{~min}$ at $25^{\circ} \mathrm{C}$. 10 volumes $(2.0 \mathrm{ml})$ of $1 \%$ sodium dodecyl sulfate (SDS) in $10 \mathrm{mM}$ EDTA, pH 7.0 was added to stop the reaction, and mixed well. This lysed the nuclei and resulted in a clear viscous solution.

Extraction of RNA. After the transcription reaction was stopped onetenth $(200 \mu \mathrm{l})$ of $3 \mathrm{M}$ sodium acetate, $\mathrm{pH} 5.0$ was added and mixed. An equal volume of $2.5 \mathrm{ml}$ phenol-chloroform (2:1) was then added and mixed well. The mixture was incubated at $60^{\circ} \mathrm{C}$ for $15 \mathrm{~min}$, and shaken vigorously several times, cooled on ice and centrifuged at $10,000 \mathrm{~g}$ for $10 \mathrm{~min}$ at $4^{\circ} \mathrm{C}$. The upper aqueous phase was recovered avoiding the interface. This phase was further extracted in $2.5 \mathrm{ml}$ of chloroformisoamylalcohol (24:1). $2.5 \mathrm{vol}(7.5 \mathrm{ml})$ of absolute ethanol was added to the aqueous phase and incubated at $-20^{\circ} \mathrm{C}$ for $16 \mathrm{~h}$ to precipitate the RNA. The RNA was recovered by centrifugation at $10,000 \mathrm{~g}$ for $20 \mathrm{~min}$ at $4^{\circ} \mathrm{C}$, the ethanol was decanted, and the RNA (pellet) was rewashed by resuspending the pellet in cold ethanol. Incubation at $-70^{\circ} \mathrm{C}$ for $1 \mathrm{~h}$ was followed by reprecipitating the RNA, and centrifuging at $10,000 \mathrm{~g}$ for $20 \mathrm{~min}$ at $4^{\circ} \mathrm{C}$. The ethanol was decanted and the RNA pellet dried under vacuum, and then dissolved in $100 \mu \mathrm{l}$ of sterile water. An aliquot $(2 \mu \mathrm{l})$ was removed for determining total input cpm (usually $5-10 \times 10^{6}$ cpm). Total radioactivity incorporated into the nuclear RNA was determined by blotting $2-\mu l$ aliquots of the transcription reaction to DE81 filters, washing with dibasic sodium phosphate, and counting as described (29).

Quantitation of $\left[{ }^{32} P\right] R N A$ by hybridization to immobilized DNA. The DNA (rGH \& pBR322 plasmid) was denatured by boiling for 5 min, followed by quick cooling on ice. DNA $(2 \mu \mathrm{g})$ was spotted onto a nitrocellulose paper (NC) and immobilized in a vacuum minifold. After baking the NC sheet in a vacuum oven at $80^{\circ} \mathrm{C}$ for $2 \mathrm{~h}$, the paper, cut into strips, was placed in a polyethylene bag with $1 \mathrm{ml}$ prehybridization buffer consisting of $50 \%$ deionized formamide, $5 \times$ SSC $(1 \times$ SSC equals $0.15 \mathrm{M}$ sodium chloride, $0.015 \mathrm{M}$ sodium citrate), $0.1 \% \mathrm{SDS}, 10 \mathrm{mM}$ Tris $\mathrm{HCl} \mathrm{pH}$ 7.0, $2 \mathrm{mM}$ EDTA, $5 \times$ Denhardt's solution, denatured salmon sperm DNA ( $200 \mu \mathrm{g} / \mathrm{ml})$, and $5 \mu \mathrm{g} / \mathrm{ml}$ synthetic poly-(A) RNA. $\mathrm{NC}$ was then incubated in a $52^{\circ} \mathrm{C}$ water bath for $3 \mathrm{~h}$ prehybridization. The prehybridization buffer was then replaced with $0.9 \mathrm{ml}$ of fresh prehybridization buffer, and $0.1 \mathrm{ml}$ of the appropriate amount of the $\left.{ }^{32} \mathrm{P}\right]$ RNA probe $\left(>10^{6} \mathrm{cpm}\right)$. The bag was carefully sealed, mixed gently but thoroughly, and incubated in a $52^{\circ} \mathrm{C}$ water bath for $3 \mathrm{~d}$. The labeled RNA was therefore hybridized in $45 \%$ formamide against duplicate dots of immobilized rGH cDNA and pBR322 plasmid DNA (28).

In all experiments, $\left[{ }^{3} \mathrm{H}\right] \mathrm{GH}$ cRNA $(1,000 \mathrm{cpm})$ prepared as described below was also added to the hybridization mixture. This served as an internal standard of hybridization efficiency.

Wash and development. After hybridization, the bag was opened and the NC filter was placed in a tray with $100 \mathrm{ml}$ of $2 \times$ SSC, $0.1 \%$ SDS and agitated gently for $10 \mathrm{~min}$ at room temperature. This wash procedure was repeated four times. Three further 30 -min washes were then performed at 50,55 , and $60^{\circ} \mathrm{C}$, respectively, in $0.1 \times$ SDS and $0.1 \%$ SSC. The NC paper from some experiments was blotted with paper towels, dried, and wrapped in Saran wrap and then autoradiographed. X-ray film was exposed at $-70^{\circ} \mathrm{C}$, using intensifying screens, for 3-5 d, and then developed. In other experiments, the amount of $\left.{ }^{32} \mathrm{P}\right] \mathrm{RNA}$ bound to each dot of DNA was quantified by radioactive counting of punched- out NC dots. Each dot of immobilized DNA was punched out from the filter strips and the radioactivity was determined by liquid scintillation counting ( $10 \mathrm{ml}$ Aquasol) for $20 \mathrm{~min}$. A minaxi-beta Tricarb 4000 liquid scintillation counter (Packard Instrument Co., Inc., Downers Grove, IL) was used. The window ranges for ${ }^{32} \mathrm{P}$ and ${ }^{3} \mathrm{H}$ were $16-1,700$ and $0-16$, respectively. The ${ }^{3} \mathrm{H}-\mathrm{cpm}$ were corrected for a $3 \%$ overlap of ${ }^{32} \mathrm{P}$. The contribution of the ${ }^{3} \mathrm{H}-\mathrm{cpm}$ to the ${ }^{32} \mathrm{P}-\mathrm{cpm}$ was negligible $(<0.03 \%)$. The background was determined by counting a similar sized dot from a same portion of the filter where no DNA was bound and by determining the amount of radioactive RNA bound to a dot of pBR322 DNA (nonspecific counts). The rate of mRNA synthesis was calculated by dividing the specific radioactivity hybridized to GH CDNA by the input radioactivity in parts per million (ppm). A correction was made for the hybridization efficiency determined by hybridization of the internal $\left[{ }^{3} \mathrm{H}\right] \mathrm{CRNA}$ standard.

Preparation of pituitary $m R N A$. In order to prepare large amounts of unlabeled mRNA to be used for competition of hybridization, rat pituitary polyadenylated(polyA)RNA was prepared. 10 rat pituitary glands were collected after decapitation. Total RNA was extracted using guanidinium isocyanate and hot phenol (30). Poly(A)RNA was obtained by chromatography over oligo (dT) cellulose columns (31). $226 \mu \mathrm{g}$ of total pituitary RNA yield $6 \mu \mathrm{g}$ of poly(A)RNA.

GH $c D N A$ insert preparation. $50 \mu \mathrm{g}$ ethanol precipitable plasmid (4,362-nucleotide $\mathrm{pBR} 322$ vector containing 800-nucleotide rGH cDNA insert kindly provided by Dr. John Baxter and Dr. Norman Eberhardt, University of California, San Francisco [32]) was digested with Hind III $(0.6 \mathrm{U} / \mathrm{ml})$ and incubated with $50 \mathrm{mM} \mathrm{NaCl}, 10 \mathrm{mM}$ Tris $\mathrm{HCl}$ (pH 7.5), $10 \mathrm{mM} \mathrm{MgCl}_{2}, 1 \mathrm{mM}$ DTT for $2 \mathrm{~h}$ at $37^{\circ} \mathrm{C}$. After digestion, the plasmid was electrophoresed on a $1 \%$ agarose gel in $0.089 \mathrm{M}$ Tris-borate, 0.089 $\mathrm{M}$ boric acid, $2 \mathrm{mM}$ EDTA pH 8.0 containing $0.5 \mu \mathrm{g} / \mathrm{ml}$ ethidium bromide. After minigel electrophoresis, the 800 -basepair (bp) insert was collected on NE-45 strip paper ( $0.45 \mu \mathrm{m}$; Schleicher \& Schuell, Inc., Keene, $\mathrm{NH})$ and eluted with phenol. After ethanol precipitation, the insert was reprecipitated with $0.3 \mathrm{M}$ sodium acetate to remove the $\mathrm{NaCl}$ residue. The cDNA plasmid insert for rat PRL (33) was kindly provided by Dr. John Baxter and the plasmid was propagated as described (34).

${ }^{3} \mathrm{H}$-labeled $\mathrm{GH}$ cRNA preparation. The following modifications of the method of McKnight and Palmiter (35) were used to isolate $\left[{ }^{3} \mathrm{H}\right] \mathrm{GH}$ cRNA. GH cRNA was obtained from the Hind III digested GH cDNA insert using Escherichia coli RNA polymerase (New England Nuclear, Boston, MA). $2 \mu \mathrm{g}$ of this DNA were suspended in $25 \mu \mathrm{l}$ of reaction buffer containing a final concentration of $40 \mathrm{mM}$ Tris, $\mathrm{HCl} \mathrm{pH} \mathrm{8.0,10}$ $\mathrm{mM} \mathrm{MgCl} 2,1 \mathrm{mM}$ DTT, $1 \mathrm{mM} \mathrm{K}_{2} \mathrm{HPO}_{4}, 50 \mathrm{mM} \mathrm{KCl}, 10 \%$ glycerol, $0.5 \mathrm{mM}$ each of GTP, CTP, and ATP, and $300 \mathrm{U} / \mathrm{ml} E$. coli RNA polymerase, and $0.1 \mathrm{mCi}$ of evaporated $\left[{ }^{3} \mathrm{H}\right] \mathrm{UTP}(33.7 \mathrm{Ci} / \mathrm{mmol}$, New England Nuclear). The reaction mixture was incubated at $37^{\circ} \mathrm{C}$ for $2 \mathrm{~h}$, diluted with $200 \mu$ l of DNase buffer ( $20 \mathrm{mM}$ Hepes, $\mathrm{pH} 7.5,5 \mathrm{mM} \mathrm{Mg}$ $\mathrm{Cl}_{2}, 1 \mathrm{mM} \mathrm{CaCl}_{2}, 1 \mathrm{mM} \mathrm{MnCl}$ ) and digested at $37^{\circ} \mathrm{C}$ for $60 \mathrm{~min}$ with $10 \mu \mathrm{g} / \mathrm{ml}$ of DNase I (Bethesda Research Laboratories, Gaithersburg, MD). The DNase was removed by adding $20 \mu \mathrm{l}$ of $10 \%$ SDS, $50 \mathrm{mM}$ EDTA, $100 \mathrm{mM}$ Tris $\mathrm{HCl}$, and $10 \mu \mathrm{g}$ of proteinase $\mathrm{K}$ (Boehringer Mannheim Diagnostics, Inc., Houston, TX) followed by a 60 -min incubation at $37^{\circ} \mathrm{C}$. After adding $10 \mu \mathrm{g}$ of $E$. coli tRNA as carrier, phenol/chloroform (1:1) extraction was performed. After two chloroform extractions, the RNA was recovered by ethanol precipitation $\left(-20^{\circ} \mathrm{C}\right.$, overnight). The pellet was dissolved in $500 \mu \mathrm{l}$ of gel buffer $(0.3 \mathrm{M} \mathrm{NaCl}, 0.1 \%$ SDS, 1 mM EDTA, $10 \mathrm{mM}$ Tris $\mathrm{HCl} \mathrm{pH}$ 7.5). The labeled cRNA was purified by chromatography on a column $(0.5 \times 10 \mathrm{~cm})$ of Sephadex G-50 and the RNA was recovered by ethanol precipitation. The final pellet was dissolved in $1 \mathrm{ml}$ of $20 \mathrm{mM}$ Tris $\mathrm{HCl} \mathrm{pH} 8.0,50 \mathrm{mM} \mathrm{NaCl}, 6 \mathrm{mM}$ $\mathrm{MgCl}_{2}$, and stored at $-20^{\circ} \mathrm{C}$ until used.

Materials. Insulin receptor antiserum (B9) was kindly provided by Dr. Ron Kahn, Joslin Clinic, Boston, MA. This antiserum is specific for the insulin receptor (33), and has been shown to inhibit the suppressive effect of insulin on pituitary GH mRNA levels (11). Guinea-pig antiinsulin serum was purchased from Biotek Research, Inc., Lenexa, KS. Fetal calf serum was purchased from Sterile Systems, Logan, UT. Hormone supplements were purchased from Collaborative Research, Inc., 
Lexington, MA and culture media were obtained from Irvine Scientific, Santa Ana, CA. All hormones were of culture grade and sterile-filtered.

\section{Results}

\section{$R N A$ synthesis in isolated nuclei}

The nuclear run-off assay was performed as a reflection of in vitro $\mathrm{GH}$ gene transcription. $10^{7}$ cells were harvested after $4 \mathrm{~h}$ incubation in serum-free medium with or without added insulin $(0.7,3.5$, and $7 \mathrm{nM}$, respectively). Nuclei were then isolated and incubated in the transcription reaction. The time course of the incorporation of total radioactive GTP into the isolated nuclei is shown in Fig. 1. Aliquots $(2 \mu \mathrm{l})$ of the transcription reaction were transferred at the indicated times to DE-81 filters and after washing with dibasic sodium phosphate, were counted. By 30 min, $\sim 5 \%$ of added $\left[{ }^{32} \mathrm{P}\right]$ GTP was incorporated into nucleic acids. Insulin treatment of the cells for $4 \mathrm{~h}$ before the isolation of cell nuclei did not alter the rate of total $\left[{ }^{32} \mathrm{P}\right] \mathrm{GTP}$ incorporation into RNA.

\section{Synthesis of GH mRNA}

The synthesis of GH mRNA was quantified by hybridization of the newly synthesized $\left[{ }^{32} \mathrm{P}\right] \mathrm{RNA}$ with excess immobilized GH cDNA (Table I). For each blot of GH cDNA ( $2 \mu \mathrm{g})$ immobilized, a companion blot of pBR322 $(2 \mu \mathrm{g})$ was made on the same nitrocellulose strip for each experiment. The nonspecific $\mathrm{cpm}$ counted from the pBR322 spots were subtracted from the cpm of the GH hybridization signal. When the specific hybridization of the newly synthesized GH mRNA was corrected for the hybridization efficiency determined by $\left[{ }^{3} \mathrm{H}\right] \mathrm{GH}$ cRNA hybridization (30-48\%), the rate of new GH mRNA synthesis ranged from 25.8 to $44 \mathrm{ppm}$ in 12 independent experiments. Addition of alpha-amanitin, an inhibitor of RNA polymerase II, to the

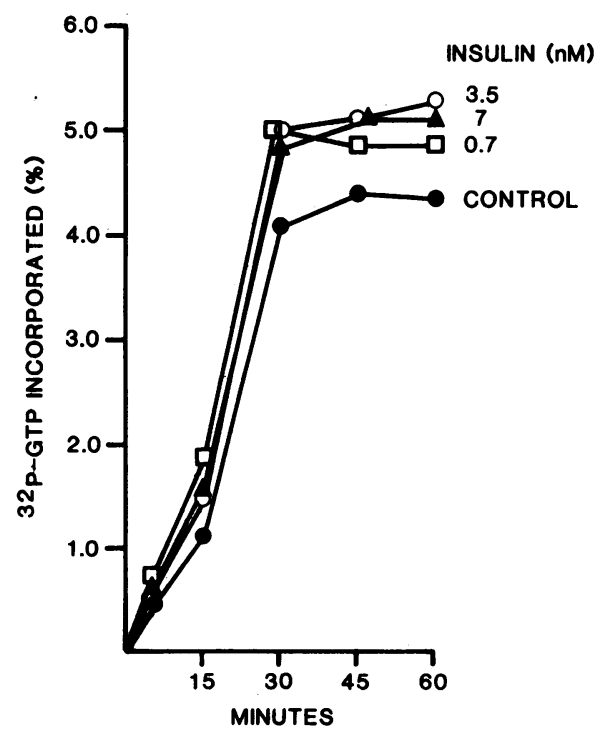

Figure 1. Rate of incorporation at $\left[{ }^{32} \mathrm{P}\right] \mathrm{GTP}$ into isolated nuclei derived from insulin-treated or control untreated cells. $\mathbf{G H}_{3}$ cells growing in monolayer were incubated for $4 \mathrm{~h}$ with or without insulin in serum-free medium. Cell nuclei were isolated and incubated for up to $60 \mathrm{~min}$ at $25^{\circ} \mathrm{C}$ with $\left[{ }^{32} \mathrm{P}\right]$ GTP in the transcription reaction buffer. At each time point, 2- $\mu$ l aliquots of the suspension were removed, spotted on DE-81 paper, and counted after elution with dibasic sodium diphosphate.
Table I. Growth Hormone Transcriptional Activity in Isolated Cell Nuclei

\begin{tabular}{|c|c|c|c|c|c|}
\hline & \multirow[b]{2}{*}{ Input $\left[{ }^{32} \mathrm{P}\right]$} & \multicolumn{2}{|c|}{$\begin{array}{l}{\left[{ }^{32} \mathrm{P}\right] \mathrm{RNA}} \\
\text { hybridized }\end{array}$} & \multirow{2}{*}{$\begin{array}{l}{\left[{ }^{3} \mathrm{H}\right] \mathrm{cRNA}} \\
\text { hybridized }\end{array}$} & \multirow{2}{*}{$\begin{array}{l}\text { mRNA } \\
\text { synthesis }\end{array}$} \\
\hline & & $\mathrm{rGH}$ & pBR322 & & \\
\hline & $\mathrm{cpm} \times 10^{6}$ & cpm & cpm & percent & $p p m$ \\
\hline \multicolumn{6}{|l|}{$\mathrm{GH}_{3}$ cell nuclei } \\
\hline \multirow[t]{7}{*}{ Controls } & 36 & 532 & 61 & 37 & 40 \\
\hline & 11.06 & 141 & 20 & 25.7 & 42.1 \\
\hline & 11.06 & 142 & 20 & 23.2 & 47.4 \\
\hline & 7.05 & 142 & 2 & 44.8 & 44.2 \\
\hline & 7.05 & 149 & 2 & 46.3 & 44.9 \\
\hline & 5.3 & 42 & 2 & 29.2 & 25.8 \\
\hline & 3.25 & 44 & 6 & 27.6 & 42.4 \\
\hline \multicolumn{6}{|l|}{ Alpha-amanitin } \\
\hline$(0.1 \mu \mathrm{g} / \mathrm{ml})$ & 2.9 & 14 & 2 & 30.0 & 13.8 \\
\hline Alpha-amanitin & & & & & \\
\hline$(1 \mu \mathrm{g} / \mathrm{ml})$ & 2.7 & 2 & 2 & 31.0 & N.D. \\
\hline \multicolumn{6}{|l|}{ Tissue nuclei } \\
\hline $\mathrm{GH}_{3}$ cell & 5.9 & 85 & 13 & 34.0 & 35.9 \\
\hline Liver & 5.9 & - & - & 31.6 & N.D. \\
\hline
\end{tabular}

Transcriptional assays were performed on nuclei isolated from $10^{7} \mathrm{GH}_{3}$ cells in each treatment group. Alpha-amanitin was added to the in vitro nuclear runoff assay when indicated. Liver nuclei were isolated from fresh rat liver tissue. Background hybridization to DNA-free paper ranged from $<1$ to $44 \mathrm{cpm}$. N.D., not detectable.

transcription reaction, inhibited the synthesis of new mRNA. Alpha-amanitin $(0.1 \mu \mathrm{g} / \mathrm{ml})$ inhibited incorporation of $\left[{ }^{32} \mathrm{P}\right] \mathrm{GTP}$ into GH mRNA to $14 \mathrm{ppm}$, and new synthesis of GH mRNA was totally suppressed by $1 \mu \mathrm{g} / \mathrm{ml}$. In contrast, undetectable GH mRNA synthesis was found when isolated rat liver nuclei were also incubated in the transcription reaction.

Varying the input from 1 to $36 \times 10^{6} \mathrm{cpm}$ did not alter the rate of new GH mRNA synthesis. To validate that the quantity of immobilized GH cDNA was sufficient to provide excess hybridization capacity for the amount of radioactive RNA added, experiments were performed using varying doses (0.5-8 $\mu \mathrm{g})$ of immobilized GH cDNA. When the input cpm was kept constant $\left(3.45 \times 10^{6} \mathrm{cpm} / \mathrm{ml}\right.$ hybridization buffer) and the cDNA concentration varied, no differences in either GH mRNA synthesis $(44.7 \pm 1.8 \mathrm{ppm})$ or hybridization efficiency $(36.7 \pm 1.3 \%)$ were noted.

The fidelity of the GH hybridization was also checked by testing the inhibition of hybridization by pituitary RNA. When poly(A)-RNA extracted and prepared from 10 rat anterior pituitary glands was added to the hybridization buffer, the binding of [ $\left.{ }^{32} \mathrm{P}\right] \mathrm{RNA}$ to the immobilized cDNA was inhibited in a dosedependent manner. This poly(A)-RNA was not pure GH mRNA but nevertheless, $250 \mathrm{ng}$ of poly(A)-RNA suppressed hybridization of $\left[{ }^{32} \mathrm{P}\right] \mathrm{GH}$ mRNA by $80 \%$.

\section{Effects of insulin on GH gene transcriptional activity}

Dose response. $\mathrm{GH}_{3}$ cells were grown to near confluency for 7 d. Medium was then replaced with serum-free defined medium containing 0.7 to $70 \mathrm{nM}$ insulin and incubations continued for $4 \mathrm{~h}$. Control cells did not receive added insulin. After isolation of the nuclei, new GH mRNA synthesis was measured in the run-off assay for $45 \mathrm{~min}$ at $25^{\circ} \mathrm{C}$. As shown in Fig. 2, control nuclei continued to synthesize new GH mRNA (41.8 $\pm 0.6 \mathrm{ppm}$, $n=4$ separate transcription reactions). Treatment with increasing 


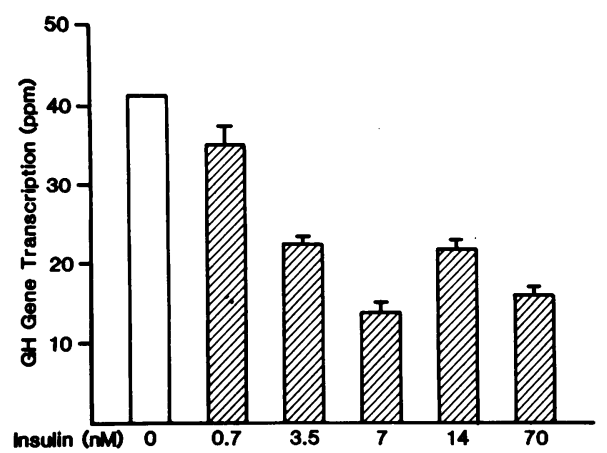

Figure 2. Dose response of the insulin effect on GH gene transcription. $\mathrm{GH}_{3}$ cells growing in serum-free medium were treated with insulin (up to $70 \mathrm{nM}$ ) or without added insulin, for $4 \mathrm{~h}$. Cell nuclei were then isolated and incubated with $\left.{ }^{32} \mathrm{P}\right] \mathrm{GTP}(200 \mu \mathrm{Ci})$ in the transcription reaction for $45 \mathrm{~min}$ at $25^{\circ} \mathrm{C}$. New GH mRNA synthesis was measured by hybridization against immobilized GH cDNA $(2 \mu \mathrm{g} / \mathrm{dot})$. Each hybridization reaction also included a companion immobilized pBR322 DNA dot. $\left[{ }^{3} \mathrm{H}\right] \mathrm{GH}$ cRNA $(1,000 \mathrm{cpm})$ was also added to each hybridization mixture to assess hybridization efficiency. New GH mRNA synthesis (ppm) was calculated by dividing the specific hybridized cpm (minus nonspecific bound pBR322 cpm) by the input cpm $\left(5-10 \times 10^{6} \mathrm{cpm}\right)$ and correcting for hybridization efficiency. Bars represent mean and range of duplicate dots from a representative experiment. Each transcription reaction was performed on nuclei yielded from at least $10^{7}$ cells.

doses of insulin caused a progressive decrease in the rate of new GH mRNA synthesis. The lowest insulin dose tested $(0.7 \mathrm{nM})$ suppressed GH mRNA synthesis to $35.5 \pm 2.1$ (mean \pm range) ppm. Maximal suppression of GH transcriptional activity was achieved by $7 \mathrm{nM}$ insulin $(13.5 \pm 2.1 \mathrm{ppm})$. Increasing the insulin dose to $70 \mathrm{nM}$ did not further suppress the $\mathrm{GH}$ transcriptional activity. When insulin was added to the cells either immediately after removal of serum-containing medium, or after cells had been grown in serum-free medium for 24 to $48 \mathrm{~h}$, no differences in inhibition of $\mathrm{GH}$ gene transcription were seen.

Time course. $\mathrm{GH}_{3}$ cells were incubated in serum-free medium with or without added insulin (7 $\mathrm{nM})$ for 1-72 h. At each time point, medium was aspirated and the nuclei were immediately isolated for assay of $\mathrm{GH}$ transcriptional activity. For each time point, new mRNA synthesis was measured in control untreated cells, and in insulin-treated cells. As shown in Fig. 3, maximal inhibition of new GH mRNA synthesis was seen after $4 \mathrm{~h}$ of insulin treatment as compared with untreated cells. $(31 \pm 6 \%$ of control values, $n=6$ separate experiments). After $72 \mathrm{~h}$, transcriptional rates in the insulin-treated cells had recovered to $81 \pm 6 \%$ of control values.

Specificity of the insulin effect. The specificity of inhibitory effect of insulin on GH gene transcription was tested by using a guinea pig anti-insulin serum (Fig. 4). The antiserum (1:2,000) was added to the cultures $1 \mathrm{~h}$ before insulin treatment. Cells in control wells were also exposed to similar titers of nonimmune guinea pig serum. After $4 \mathrm{~h}$ treatment, isolated nuclei were subjected to the transcriptional runoff assay. At that time, not only new GH mRNA, but also prolactin mRNA synthesis were measured by hybridization against both immobilized GH cDNA and prolactin cDNA ( $2 \mu \mathrm{g} / \mathrm{dot}$ each), respectively. Insulin (7 nM) did not alter new PRL mRNA synthesis, although GH mRNA synthesis was clearly inhibited by insulin in the same cells by $\sim 75 \%$. Anti-insulin serum alone did not alter the rate

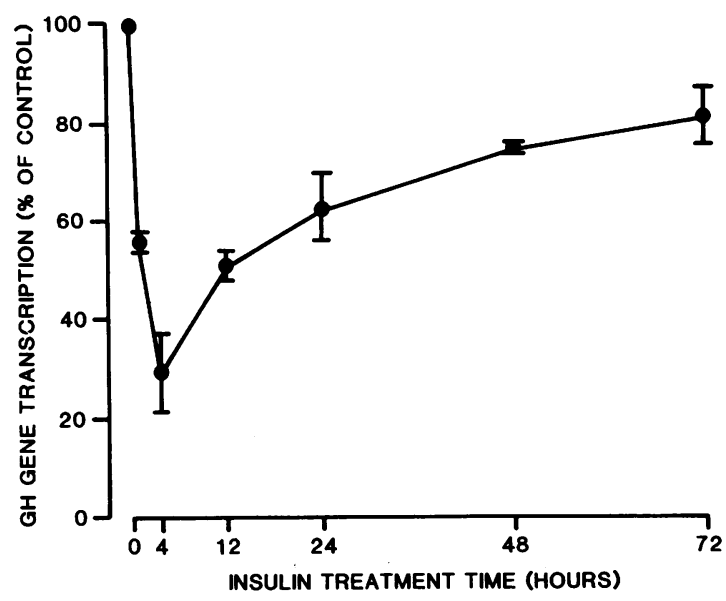

Figure 3. Time course of the insulin effect on GH gene transcriptional activity. $\mathrm{GH}_{3}$ cells were treated with added insulin $(7 \mathrm{nM})$ for $1-72 \mathrm{~h}$. At each time indicated, incubations of $10^{7}$ cells were terminated and nuclei isolated for the transcriptional runoff assay as described in Methods. For each point, the ppm was compared with respective controls incubated for the same time with no added insulin. Each point represents mean $\pm S D$ of 3-6 separate transcriptional reactions.

of new GH mRNA synthesis, but did prevent the inhibitory effects of insulin on $\mathrm{GH}$ gene transcriptional activity.

To further test the specificity of the insulin effect, we incubated cells in the presence of insulin receptor antiserum (B9). As shown in Fig. 5, this serum (final titer, 1:4,000) also prevented the insulin-induced suppression of new GH mRNA synthesis. In this experiment, control cells were incubated with equivalent aliquots of nonimmune human serum. Furthermore, treatment of these cells with fibroblast growth factor (FGF) or epidermal growth factor (EGF) $(50 \mathrm{ng} / \mathrm{ml}$ each, respectively) did not alter the transcriptional activity of the $\mathrm{GH}$ gene. During all these control experiments, insulin itself $(7 \mathrm{nM})$ consistently inhibited new GH mRNA synthesis.

\section{Discussion}

The roles of insulin, insulin growth factor (IGF)-I and IGF-II in regulating $\mathrm{GH}$ secretion have recently received increasing attention. It has been suggested, by analogy with the thyroid (37, 38) and adrenal axes (39), that these related peptides exert a negative feedback effect on rat pituitary $(17,40-44,45)$ and human pituitary (46) GH secretion. The data presented here further extend this hypothesis by delineating a molecular mechanism for the inhibition of GH gene expression by insulin.

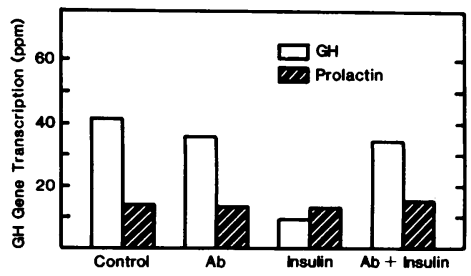

Figure 4. Specificity of insulin effect on new $\mathrm{GH}$ mRNA synthesis. $\mathrm{GH}_{3}$ cells were incubated for $1 \mathrm{~h}$ with nonimmune guinea pig serum (1:2,000 final titer) (control, insulin) or anti-insulin guinea pig serum $(\mathrm{Ab}$, $\mathrm{Ab}+$ insulin). This was followed by $4 \mathrm{~h}$ treatment with or without added insulin $(7 \mathrm{nM})$. At the end of the incubations, both GH and PRL gene transcriptional activities were measured in isolated nuclei. Each hybridization reaction (input, $3.25 \times 10^{6} \mathrm{cpm}$ ) contained separately immobilized dots of GH cDNA, PRL cDNA, and pBR322 ( $2 \mu \mathrm{g} / \mathrm{dot}$, respectively). Data shown are representative of a single experiment. 

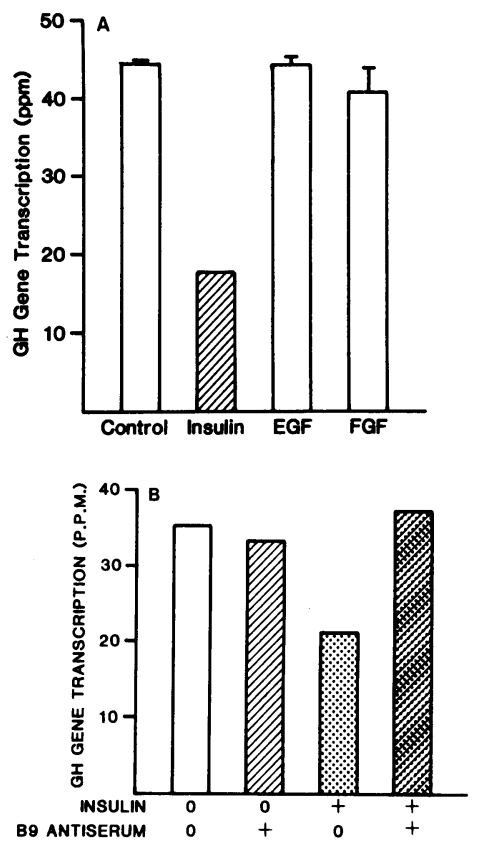

Figure 5. Specificity of insulin effect on $\mathrm{GH}$ gene transcriptional activity. $\mathrm{GH}_{3}$ cells were incubated for $4 \mathrm{~h}$ with either $(A)$ insulin, $(7 \mathrm{nM})$, EGF $(50 \mathrm{ng} / \mathrm{ml})$, or FGF $(50 \mathrm{ng} / \mathrm{ml})$, or $(B)$ insulin receptor antiserum (B9, 1:4,000), with or without added insulin (7 nM). Nuclei were then isolated and transcriptional runoff assays were performed for $45 \mathrm{~min}$. Each bar represents mean \pm range of duplicate dots $(A)$; or values from a single experiment $(B)$.

The results reported here indicate that semisynthetic purified insulin directly regulates the synthesis of nascent GH mRNA chains in $\mathrm{GH}_{3}$ rat pituitary cells. When isolated $\mathrm{GH}_{3}$ cell nuclei were allowed to continue RNA synthesis in vitro, the rates of specific incorporation of radiolabeled RNA precursor into GH mRNA, reflect $\mathrm{GH}$ gene transcription rates as far as is possible to determine (28). This approach is currently the most effective experimental approach to establish that insulin exerts a direct transcriptional effect on the GH gene. The transcriptional runoff assay was specific inasmuch as transcription rates were totally inhibited by alpha-amanitin, a known inhibitor of RNA polymerase activity (47). Furthermore, excess cold unlabeled mRNA extracted from rat pituitary tissue was able to competitively inhibit the control transcription rates.

Specific, high affinity receptors for insulin, IGF-I, and IGFII have been characterized on GH rat pituitary tumor cells (2426 ), as well as in normal rat pituitary cells (48-50). The observed dissociation constant $\left(K_{\mathrm{D}}\right)$ for insulin binding sites ranged from 0.1 to $5 \mathrm{nM}$ and these insulin receptor sites appeared to be the predominant receptor of these three peptides in the $\mathrm{GH}_{3}$ cells. The relatively low doses of insulin used in these experiments $(0.7$ to $7 \mathrm{nM})$ are unlikely to have activated an IGF-I receptor on these cells. The effects of insulin in these experiments were also inhibited by an insulin receptor antiserum (B9) which does not block the IGF-I receptor (36), further indicating the specificity of the insulin effect. We have previously shown that this titer of antiserum blocks the inhibitory effects of insulin on $\mathrm{GH}$ secretion by normal pituitary cells (11). $>200 \mathrm{nM}$ insulin was required for $50 \%$ displacement of ${ }^{125}$ I-IGF-I from its binding sites on pituitary cells (49) and $\mathrm{GH}_{3}$ cells (26). In another study, only $16 \%$ displacement of ${ }^{125}$ I-IGF-I from pituitary cell membranes occurred with exposure to $>40 \mathrm{nM}$ insulin (50). Nev- ertheless, the possibility that even the low doses of insulin used here activated an IGF-I receptor cannot be definitively excluded.

Although insulin $(7 \mathrm{nM})$ maximally inhibits the long-term GH secretion by $\mathrm{GH}_{3}$ cells, far higher $(\sim 32 \mathrm{nM})$ concentrations of a partially purified somatomedin preparation were required to elicit maximal suppression of GH secretion (22). Because of this relative insensitivity of the $\mathrm{GH}_{3}$ cells to somatomedin, IGFI was not tested in this model, but was preferably tested in a transcriptional assay in normal pituitary cells. We recently observed that a recombinant human IGF-I analog (Amgen, Thr 59) directly inhibits GH gene transcriptional activity in monolayer cultures of normal rat pituitary cells (45). Although the dose response was similar, the time course of the IGF-I effect on GH gene transcription appears to differ from that of insulin reported here, albeit in a different model. 1.3 nM IGF-I suppressed new GH mRNA synthesis, and this suppression of transcription lasted for at least $24 \mathrm{~h}$. The maximal insulin effect, however, was seen here after $4 \mathrm{~h}$, and GH transcriptional rates began recovering thereafter. The inhibitory effects of insulin were also blocked by co-incubation of cells with anti-insulin serum at similar titers $(1: 2,000)$ previously shown to abolish the effects of insulin on GH secretion by these cells (22).

Further lines of evidence suggest that the observed effects of insulin in these cells is specific. Insulin did not suppress PRL gene transcriptional activity in these cells, which suggests a selective inhibition of new GH mRNA synthesis. Thus, the above evidence suggests that insulin specifically regulates the transcriptional activity of the $\mathrm{GH}$ gene.

Insulin was shown to regulate carbohydrate metabolism (51), and total protein synthesis (52) in rat anterior pituitary tissue. Subsequently, the direct effects of insulin on in vitro expression of GH have been examined by several groups $(10,11,40,53-$ 56). Using several different systems, and differing preparations of insulin, the results of most studies have shown that insulin suppresses the secretion of $\mathrm{GH}$ by both $\mathrm{GH}_{3}$ cells and normal pituitary cells. Furthermore, insulin has also been shown to inhibit the levels of GH mRNA transcripts in $\mathrm{GH}_{3}(10)$ and normal rat pituitary cells (11). These effects were observed at insulin doses within the physiologic range and occurred independently of the presence of glucose or serum. Furthermore, the suppressive effect of insulin on GH appears to be selective, inasmuch as PRL (22), follicle-stimulating hormone, and luteinizing hormone secretion appear to be mildly stimulated by insulin (57). The data presented here indicate that the mechanism for these observed effects of insulin on GH gene expression involve a direct inhibition of GH transcriptional rates induced by insulin. This observation is further evidence for a specific role of insulin in the pituitary cellular regulation of $\mathrm{GH}$ secretion.

The inhibition of GH gene transcription by insulin occurs earlier than the inhibition of GH mRNA levels and subsequent hormone secretion by these cells. The reversal of insulin inhibition of the GH transcription rate between 4 and $72 \mathrm{~h}$ may be due to desensitization of the response or possibly to insulin degradation. Radioimmunoassayable GH secretion is inhibited by insulin in these cells after a lag-period of 24-48 h (22), GH mRNA levels also fall by $40 \%$ after $48 \mathrm{~h}$ insulin treatment reaching 50\% of control untreated mRNA levels by $72 \mathrm{~h}$. The early $50 \%$ suppression of GH transcription, seen after $4 \mathrm{~h}$, followed by a later suppression of mRNA levels and hormone secretion seen after $48 \mathrm{~h}$, is consistent with the reported 40-56-h half-life of GH mRNA in these cells (20). The shorter half-life of GH mRNA, however, reported by others (21), may indicate that 
insulin may also alter mRNA stability in addition to its transcriptional effects. Although GHRH, $\mathrm{T}_{3}$, and hydrocortisone have been shown to stimulate $\mathrm{GH}$ gene transcriptional activity (18-21, 58), this report provides evidence for inhibition of GH gene expression at the level of gene transcription. Somatostatin, although a potent inhibitor of in vivo and in vitro $\mathrm{GH}$ release, does not appear to suppress GH mRNA levels in rat pituitary cells (59). We have also recently shown, however, that IGF-I inhibits GH mRNA levels in primary rat pituitary cells (17), and this inhibition also appears to occur at the level of $\mathrm{GH}$ gene transcription (45).

These results provide further evidence for the role of insulin in regulating $\mathrm{GH}$ gene expression. Although the finding that the hypothalamic content of insulin is significantly higher than in other rat brain regions (60) is consistent with a role for insulin regulation of pituitary function, the physiologic source for pituitary insulin cannot be determined from these in vitro experiments.

The data shown here provide the first evidence for transcriptional regulation of a polypeptide hormone gene by insulin. This observation provides further insight into the molecular mechanism of insulin action at the nuclear level and is consistent with the notion of a direct regulation of $\mathrm{GH}$ gene expression by insulin.

\section{Acknowledgments}

The authors are grateful to Helen Kado for outstanding technical assistance. The GH cDNA probe was kindly provided by Dr. John Baxter and Dr. Norman Eberhardt, University of California, San Francisco, CA. The insulin receptor antiserum was kindly provided by Dr. C. Ron Kahn, Joslin Clinic, Boston, MA.

This work was supported by National Institutes of Health grants AM 34824 and AM 33802 from National Institute of Diabetes, Digestive, and Kidney Disease.

\section{References}

1. Kahn, C. R. 1985. The molecular mechanism of insulin action. Annu. Rev. Med. 36:429-451.

2. Czech, M. P. 1985. Molecular basis of insulin action. by M. P. Czech, editor. Plenum Publishing Corp., New York.

3. Granner, D., T. Andreone, K. Sasaki, and E. Beal. 1983. Inhibition of transcription of the phosphoerolpyruvate carboxykinase gene by insulin. Nature (Lond.). 305:549-551.

4. Lloyd, C. E., and L. S. Jefferson. 1985. Insulin stimulates transcription of the albumin gene in primary cultures of rat hepatocyte. Am. Diabetes Assoc. 45th Annual Meeting. (Abstr. 39)

5. Korc, M., D. Owerbach, C. Quinto, and W. J. Rutter. 1981. Pancreatic islet-acinar cell interaction: amylase messenger RNA levels are determined by insulin. Science (Wash. DC). 213:351-353.

6. Hill, R. E., K. L. Lee, and F. T. Kenny. 1981. Effects of insulin on messenger RNA activities in rat liver. J. Biol. Chem. 256:1510-1513.

7. Pry, T. A., and J. W. Porter. 1981. Control of fatty acid synthetase mRNA levels in rat liver by insulin, glucagon and dibutyryl cyclic AMP. Biochem. Biophys. Res. Commun. 100:1002-1009.

8. Naguchi, T., H. Inoue, and T. Tanaka. 1982. Regulation of rat liver L-type pyruvate kinase mRNA by insulin and by fructose. Eur. $J$. Biochem. 128:583-588.

9. Roy, A. K., B. Chatterfee, M. S. K. Prasad, and J. J. Unakar. 1980. Role of insulin in the regulation of the hepatic messenger RNA for globulin in diabetic rats. J. Biol. Chem. 255:11614-11618.

10. Melmed, S., L. Neilson, and S. Slanina. 1985. Insulin suppresses rat growth hormone mRNA levels in rat pituitary tumor cells. Diabetes. 34:408-412.

11. Yamashita, S., and S. Melmed. 1986. Effects of insulin on rat anterior pituitary cells: inhibition of growth hormone secretion and mRNA levels. Diabetes. 35:440-447.

12. Alexander, M., G. Curtis, J. Avruch, and H. M. Goodman. 1985. Insulin regulation of protein biosynthesis in differentiated 3T3 adipocytes: regulation of glyceraldehyde-3-phosphate dehydrogenase. J. Biol. Chem. 260:11978-11985.

13. Martin, J. B. 1984. Hypothalamic regulation of growth hormone secretion. In Secretory Tumors of the Pituitary Gland. P. McL. Black, N. T. Zervas, E. C. Ridgway, and J. B. Martin, editors. Raven Press, New York. 109-133.

14. Seo, H., G. Varrart, H. Brocas, and A. Refetoff. 1977. Triiodothyronine stimulates specifically GH mRNA in rat pituitary tumor cells. Proc. Natl. Acad. Sci. USA. 74:2054-2058.

15. Shapiro, L. E., H. H. Samuels, and B. M. Yaffe. 1978. Thyroid and glucocorticoid hormones synergistically control growth hormone mRNA in cultured GH cells. Proc. Natl. Acad. Sci. USA. 75:45-49.

16. Dobner, P. R., E. S. Kawasaki, L. Y. Yu, and F. C. Bancroft. 1981. Thyroid and glucocorticoid hormone induces pregrowth hormone mRNA and its probable nuclear precursor in rat pituitary cells. Proc. Natl. Acad. Sci. USA. 78:2230-2234.

17. Yamashita, S., and S. Melmed. 1986. Insulin-like growth factor I action on rat anterior pituitary cells: suppression of growth hormone secretion and mRNA levels. Endocrinology. 118:176-182.

18. Evans, R. M., N. C. Birnberg, and M. G. Rosenfeld. 1982. Glucocorticoid and thyroid hormones transcriptionally regulate growth hormone gene expression. Proc. Natl. Acad. Sci. USA. 79:7659-7663.

19. Spindler, S. R., S. H. Mellon, and J. D. Baxter. 1982. Growth hormone gene transcription is regulated by thyroid and glucocorticoid hormones in cultured rat pituitary tumor cells. J. Biol. Chem. 257:1162711632.

20. Yaffe, B. M., and H. H. Samuels. 1984. Hormonal regulation of the growth hormone gene. J. Biol. Chem. 259:6284-6291.

21. Diamond, D. J., and H. M. Goodman. 1985. Regulation of growth hormone messenger RNA synthesis by dexamethasone and triiodothyronine. Transcriptional rates and mRNA stability changes in pituitary tumor cells. J. Mol. Biol. 181:41-62.

22. Melmed, S. 1984. Insulin suppresses growth hormone secretion by rat pituitary cells. J. Clin. Invest. 73:1425-1433.

23. Goldfine, I. D., F. Purello, G. A. Clauson, and R. Vignen. 1982. Insulin binding sites on the nuclear envelope: potential relationship to mRNA metabolism. J. Cell. Biochem. 20:29-39.

24. Hollander, P., F. Stanley, and H. H. Samuels. 1979. Thyroid and glucocorticoid hormones induce insulin receptors and inhibit insulin degradation in cultured GH cells. Endocrine Society. 61 st Annual Meeting. (Abstr. 487)

25. Corin, R., F. C. Bancroft, M. Sonenberg, and D. B. Donner. 1983. Binding and degradation of ${ }^{125} \mathrm{I}$-labelled insulin by a clonal line of rat pituitary tumor cells. Biochim. Biophys. Acta. 762:503-511.

26. Rosenfeld, R. G., G. Ceda, C. W. Culter, L. A. Dollar, and A. R. Hoffman. 1985. Insulin and insulin-like growth factor (somatomedin) receptors on cloned rat pituitary tumor cells. Endocrinology. 117:2008-2016.

27. Tashjian, A. H. 1979. Clonal strains of hormone-producing pituitary cells. Methods Enzymol. 58:527-536.

28. Marluff, W. F., and R. C. C. Huang. 1984. Transcription of RNA in isolated nuclei. In Transcription and Translation. B. D. Haines and S. J. Higgins, editors. IRI press, Oxford, 89-129.

29. Spindler, S. R. 1979. Deoxyribonucleic acid-dependent ribonucleic acid polymerase II specific initiation and elongation factors from calf thymus. Biochemistry. 18:4042-4048.

30. Feramisco, J. R., J. E. Smart, K. Burridge, D. M. Helfman, and G. P. Thomas. 1982. Co-existence of viculin and a viculin-like protein of higher M.W. in a smooth muscle. J. Biol. Chem. 257:11024-11033.

31. Aviv, H., and P. Leder. 1972. Purification of biologically active globin mRNA by chromatography on oligothymidylic acid-cellulose. Proc. Natl. Acad. Sci. USA. 69:1408-1412.

32. Seeburg, P. H., J. Shine, J. B. Martial, J. D. Baxter, and H. M. 
Goodman. 1977. Nucleotide sequence and amplification in bacteria of structural gene for rat growth hormone. Nature (Lond.). 270:486-494.

33. Cooke, N. E., D. Coit, R. I. Weiner, J. D. Baxter, and J. A. Martial. 1980. Structure of cloned DNA complementary to rat PRL messenger RNA. J. Biol. Chem. 255:6502-6510.

34. Maniatis, T., E. Fritsch, and J. Sambrok. 1982. Molecular Cloning: A Laboratory Manual. Cold Spring Harbor Laboratories, Cold Spring Harbor, NY. 55-96.

35. McKnight, G. S., and R. D. Palmiter. 1979. Transcriptional regulation of the ovalbumin and conalbumin genes by steroid hormones in chick oviduct. J. Biol. Chem. 254:9050-9058.

36. Kasuga, M., H. Sasaki, C. R. Kahn, S. P. Nissley, and M. M. Rechler. 1983. Anti-receptor antibodies as probes of insulin-like growth factor receptor structure. J. Clin. Invest. 72:1459-1469.

37. Kourides, I. A., J. A. Gurr, and D. Wolf. 1984. The regulation and organization of thyroid stimulating hormone genes. Recent Prog. Horm. Res. 40:78-120.

38. Shupnick, M. A., W. W. Chin, J. F. Habener, E. C. Ridgway. 1985. Transcriptional regulation of the thyrotropin subunit genes by thyroid hormone. J. Biol. Chem. 260:2900-2905.

39. Eberwine, J. H., and J. L. Roberts. 1984. Glucocorticoid regulation of proopiomelanocortin gene transcription in the rat pituitary. J. Biol. Chem. 259:2166-2170.

40. Berelowitz, M., M. Szabo, L. A. Frohman, S. Firestone, L. Chu, and R. L. Hintz. 1981. Somatomedin-C growth hormone negative feedback by effects on both the hypothalamus and the pituitary. Science (Wash. DC). 212:1279-1281.

41. Brazeau, P., R. Guillemin, N. Ling, J. Van Wyk, and R. Humbel. 1982. Inhibition by somatomedins of growth hormone secretion stimulated by hypothalamic growth hormone releasing factor (somatocrinin, GRF) or synthetic peptide hpGRF. C. R. Acad. Sci. Paris. 295:651654.

42. Abe, H., M. E. Molitch, J. J. Van Wyk, and L. E. Underwood. 1983. Human growth hormone and somatomedin $C$ suppresses the spontaneous release of growth hormone in unanesthetized rats. Endocrinology. 113:1319-1324.

43. Tannenbaum, G. S., H. J. Guyda, and B. I. Posner. 1983. Insulinlike growth factors: a role in growth hormone negative feedback and body weight regulation via brain. Science (Wash. DC). 20:77-79.

44. Goodyer, C. C., L. De Stephano, H. J. Guyda, and B. I. Posner. 1984. Effects of insulin-like growth factors on adult male rat pituitary function in tissue culture. Endocrinology. 115:1568-1576.

45. Yamashita, S., and S. Melmed. 1986. Insulin-like growth factor I regulation of growth hormone gene transcription. Clin. Res. 34:435a.

46. Yamashita, S., M. Weiss, and S. Melmed. 1986. Insulin-like growth factor I regulates $\mathrm{GH}$ secretion and mRNA levels in human pituitary tumor cells. J. Clin. Endocrinol. Metab. 63:730-735.
47. Kedinger, C., M. Gniazclowski, J. L. Mandel, Jr., F. Gissinger, and P. Chambon. 1970. Alpha-amanitin: a specific inhibitor of one of two DNA-dependent RNA polymerase activities from calf thymus. Biochem. Biophys. Res. Commun. 38:165-171.

48. Havrankova, J., J. Roth, and M. Brownstein. 1978. Insulin receptors are widely distributed in the central nervous system of the rat. Nature (Lond.). 272:827-828.

49. Rosenfeld, R. G., G. Ceda, D. M. Wilson, L. A. Dollar, and A. R. Hoffman. 1984. Characterization of high affinity receptors for insulin-like growth factors I and II on rat pituitary cells. Endocrinology. 114:1571-1575.

50. Goodyer, C. G., L. D. Stephans, W. H. Lai, H. Guyda, and B. I. Posner. 1984. Characterization of insulin-like growth factor receptors in rat anterior pituitary, hypothalamus, and brain. Endocrinology. 114: 1187-1195.

51. Goodner, C. J., and N. Freinkel. 1961. Studiers of anterior pituitary tissue in vitro: effects of insulin and experimental diabetes mellitus upon carbohydrate metabolism. J. Clin. Invest. 60:261-270.

52. Goodner, C. J., and M. D. Krause. 1972. Studies of the effect of insulin on synthesis of electrophorectically separated proteins in anterior pituitary in vitro. Endocrinology. 90:1639-1642.

53. Vanha-Perttula, R., P. O. Kohler, and L. A. Frohman. 1970. Effect of insulin on growth hormone (GH) induction by cortisol in rat pituitary tumor cells. Life. Sci. 9:805-813.

54. Ivarie, R. D., J. D. Baxter, and J. A. Morris. 1981. Interaction of thyroid and glucocorticoid hormones in rat pituitary tumor cells: specificity and diversity of the responses analyzed by two-dimensional gel electrophoresis. J. Biol. Chem. 256:4520-4528.

55. Betteridge A., and M. Wallis. 1979. Involvement of prostaglandins in the inhibition of growth hormone production in cultured pituitary cells by insulin. J. Endocrinol. 80:239-248.

56. Melmed, S., and S. Slanina. 1985. Insulin suppresses $T_{3}$-induced growth hormone secretion by $\mathrm{GH}_{3}$ rat pituitary cells. Endocrinology. 117:532-537.

57. Adashi, E. Y., A. J. W. Hsueh, and S. S. Yen. 1980. Insulin enhancement of luteinizing hormone and follicle-stimulating hormone release by cultured pituitary cells. Endocrinology. 108:1441-1448.

58. Barinaga, M., G. Yamamoto, C. River, W. Vale, R. Evans, and M. G. Rosenfeld. 1983. Transcriptional regulation of growth hormone gene expression by growth-hormone-releasing factor. Nature (Lond.). 306:84-85.

59. Simard, J., F. Gossard, C. Kreiss, and F. Labrie. 1985. Multiple control of GH mRNA levels and GH synethesis in cultured rat anterior pituitary cells. Endocrine Society. 67th Annual Meeting. (Abstr. 479)

60. Baskin, D. G., D. Porte Jr., K. Guest, and M. Dorsa. 1983. Regional concentrations of insulin in the rat brain. Endocrinology. 112: 898-903. 